\title{
Coincidental Being and Necessity in Aquinas
}

\author{
Alejandro Llano \\ University of Navarre
}

At first sight, it may appear that Aquinas's metaphysical theory allows little space for eventuality; but contingency and accidentality have an important place and reach in St. Thomas's ontology, and implies influential consequences in his theory of action.

There has been a large group of analytic philosophers who, over some decades, have considered that the fact that behind the one word 'being' are to be found meanings as different as predication, identity, and existence, is nothing short of a disaster for the human race. According to some of them, 'metaphysics' is just another name for this disaster. But nowadays there are perhaps few who would trace the origin of metaphysics back to an original confusion of the different meanings of the verb 'to be'. This is partly because Aristotelian and Thomistic philosophers have themselves come to rediscover the richness and the rigour of the distinction between the different meanings of being which can be found within a realist metaphysics. ${ }^{1}$

The criticism which analytic philosophy has made has been the signal for the opening up of a field of study which is of the greatest

1 Cf. INCIARTE, F.: 'Ser veritativo y ser existencial", Anuario Filosófico, $\mathrm{XIII} / 2,1980$. 


\section{TOPICOS}

importance for metaphysics, even when the criticism is left behind. This is because, as Brentano said in his doctoral thesis on the many senses of being, "the discussion of the several senses of being form the threshold of Aristotle's Metaphysics". ${ }^{2}$ There is yet more reason to affirm this of the metaphysics of St. Thomas. His treatment of the many senses of being is enriched by the greater depth which his creationist vision of reality brings with it, and by the increased refinement of the semantic analysis he is able to apply, as a result of the development of medieval logic.

Thomas Aquinas makes more than one classification of the senses of being. But the clearest, the most complete, and the most important, from a metaphysical point of view, is the classification that derives from a list of four headings. I do not say "a fourfold division of senses", since a straightforward list of senses would give us at least fifteen. Aquinas's division is into four rough chapters or families of meanings. Strictly speaking, the senses which are derived from this classification are not senses which can be counted together, as if each were a separate element from all the others. Each heading provides a different semantic or ontological sphere: each arises from a different kind of criterion of distinction.

The text of St. Thomas in which these characteristics are to be found most clearly is in Book Six of the Commentary on the Metaphysics: "Being, said without qualification, i.e., said universally, is said in many ways, as was maintained in the fifth book. In one way, it is said coincidentally (secundum accidens). In another way, being is said as the same as the truth of a proposition, and nonbeing as its falsehood. In a third way, being is said as that which contains within it the figures of the predicaments, e.g., what, of what

2 Brentano, F.: On the Several Senses of Being in Aristotle, edited and translated by Rolf GEORGE, Berkeley-Los Angeles, University of California Press, 1981, p.2. 
kind, how much, etc. In a fourth way, in addition to all these, it is said in a way that is divided into potentiality and actuality". 3

The advantage of this text over others ${ }^{4}$ is to be found in the fact that here the ordering of the senses of being draws attention more clearly to the way in which the different points of view taken up in each of its four headings follow one from another:

1. Ens per accidens, coincidental being, is distinguished from ens per se, being in its own right, from a formally logical-semantic point of view.

2. Ens ut verum, being in the sense of the true, is to be found within a materially logical-semantic dimension.

3. The division of being which arises from a consideration of the figures of predicatiun reaches an ontological, categorial level.

4. Being as potentiality and being as actuality match an ontological consideration that arises on a transcendental level.

What we have here, then, is a progressive approach from being as it is in the mind and in language to being as it is in reality. Bearing this in mind, we can draw attention to other more basic way of grouping these senses of being: while the first and second headings have to do with being in propositions, the third and fourth have to do with being in reality.

St. Thomas, following Aristotle, allows for this latter distinction by drawing attention to the fact that only the latter pair of groups of

3 In VI Metaphysicorum, lect. 2, n. 1171; cf. Metaphysics, VI, 2, 1026 a 33-1026 b 2.

4 Cf. In V Metaphysicorum, lect. 9, nn. 885-897; Metaphysics, V, 7, 1017 a $7,22-24,31-33 ; 1017$ a 35-1017 b 2. 


\section{TOPICOS}

meanings -the categories and actuality and potentiality- are to be found as part of being in so far as being, the object of metaphysics.

Aquinas gives three reasons for excluding ens ut verum and ens per accidens from being the principal object of metaphysical consideration:

1. The composition and division -the affirmative or negative predication- which the intellect makes when it forms propositions may indeed be founded on the real composition and division of the objects considered, but are not to be identified with this real composition or division. Hence the composition or division with which the intellect puts together its concepts or puts them apart, is to be found only in the intellect and not in reality. The kinds of being which take shape in the intellect -i.e., ens ut verum and, as we shall see, ens per accidensare not to be counted among the kinds of being properly so called, i.e., among things outside the mind (quae sunt res extra animam). ${ }^{5}$

2. Metaphysics is the science of the ultimate causes of what is real. But ens per accidens has an indeterminate cause, and so does not fall under the consideration of any kind of art or science. The cause of ens ut verum, on the other hand, is some affection of the mind (aliqua passio mentis), and hence it is the science of the intellect that considers ens ut verum, not metaphysics. ${ }^{6}$

3. Both ens ut verum and ens per accidens refer us back to another kind of being which they presuppose, and on which they are founded. They do not have directly to do with ens simpliciter per se quod est in rebus. They do not show us any other kind of real being, other than ens per se. In the case of ens per accidens, this is clear: it arises from the accidental concomitance of several beings that exist outside the mind, each one of which is an ens per se. For example, Pale Socratés

5 In VI Metaphysicorum, lect. 4, n. 1241.

6 In VI Metaphysicorum, lect. 4, n. 1241. 
is an ens per accidens, but both Socrates and this pale are entia per $s e$. Each of them, considered in itself, has a determinate cause, but the complex formed by their coincidence has no determinate cause. ${ }^{7}$

Thus ens per accidens is not studied as such by metaphysics nor by any other science, since it has no such: it is not necessary but indeterminate, and thus does not have an ordered cause. Its causes are infinite and have no ordering one to another. ${ }^{8}$ There is no science of ens per accidens, because it is not something that exists universally, nor always exists, nor necessarily exists: it exists by chance, by coincidence. Strictly speaking, ens per accidens is not something that is or exists at all, but rather something that happens, that occurs (accidit) ${ }^{9}$ If there were a science of ens per accidens, this would mean that everything that happens has a per se cause, and thus that everything that happens happens by necessity: something that Aquinas would never admit. ${ }^{10}$

Ens per accidens, then, is only a coincidence, a coincidental. being. ${ }^{11}$ This does not mean that it has no relevance to Aquinas's metaphysics. Indeed, Aquinas's metaphysics would be impossible without the use of this highly improper and divergent sense of being. A scientific consideration of the proper object of metaphysics -ens per $s e$, that which exists in its own right- is only possible against the background of that which happens without a proper cause and without internal coherence.

7 In VI Metaphysicorum, lect. 4, n. 1243.

8 In XI Metaphysicorum, lect. 8, n. 2283.

9 In XI Metaphysicorum, lect. 8, n. 2276.

10 Cf. In XI Metaphysicorum, lect. 8, n. 2280.

$11 \mathrm{Cf}$. KIRwan, C. Aristotle's Metaphysics, books Gamma, Delta and Epsilon, Clarendon, Oxford, 1971, pp. 143 ff.; SoraBJI, R.: Necessity, Cause and Blame, Duckworth, London, 1980, pp. 4 ff. Recent Thomists, such as A. Kenny and C. Martin. have used Kirwan's excellent expression in translating Aquinas's ens per accidens. 


\section{TOPICOS}

We can begin the task of clarifying the meaning of coincidental being with a suggestion that Brentano makes with regard to Aristotle: "He gives one example in particular which serves to illustrate this improper mode of existence which belongs to the on kata symbebekos. He says that negative entities, too, such as the nonwhite, exist kata symbebekos, since the objects exist to which they belong accidentally. ${ }^{12}$ Negation as such certainly does not have real existence on its own; yet, if a person is black, I can say that the black is alive and exists as a man; with equal justification I can say that the non-white exists, not merely as something which is non-white, but as man". 13

As Professor Millán-Puelles has pointed out, the stress Brentano lays on the improperness of the existence of negation is not justified by Aristotle's text. ${ }^{14}$ The terms used are einai and $e s t i$, which can be understood in an essentialist sense as well as in an existentialist one. Indeed, negations, and, to an appropriate extent in each case, other coincidental beings, cannot have a proper existence precisely because they do not have a proper essence. No ens per accidens exists in virtue of its essence, since no ens per accidens has an essence. It exists in virtue of something extrinsic to it. Hence Millán-Puelles proposes as a description of ens per accidens "that which a being is, or that which is a being, in virtue of something extrinsic to its essence".

12 "In this sense, too, the not pale is said to be; because that of which it is an accident is". Metaphysics, V, 7, 1017 a 18.

13 BRENTANO, op. cit., p. 9. On the basis of this coincidental existence of instantiated negation or privation, we are able to speak of the ens ut verum of negation or privation as such. Evil exists, as blindness exists, with esse ut verum, because of the truth of some proposition which says that this or that animal or human being is blind or is bad, thus expressing a coincidental existence.

14 Metaphysics, V, 7, 1017 a 18-19. 
It is not surprising, then, that St. Thomas, following Aristotle, goes so far as to say that ens per accidens is close to non-being. This is why sophistry, which has to do with that which seems rather than that which is, pays special attention to the per accidens. ${ }^{15}$ This is shown in the fact that coincidental beings, since they do not have a proper nature, are not geinerated or corrupted as are beings in their own right. The same is true of negations, privations, coincidences, chance meetings: everything that happens rather than exists. As Aquinas says, "in omnibus enim his, esse nihil aliud significat quam accidere" 16 We can say of that which merely happens that it is or exists, but properly speaking it is not, does not exist: "For the accidental exists only in name". 17

Is coincidental being, then, wholly lacking in reality? No, it has a certain reality, only not in the proper sense in which that which exists in its own right has reality. It has reality in the ontologically improper sense in which occurrences or facts have reality. But occurrences or facts can be treated as if they were beings, though their coherence, their internal unity, is not something that they have in their own right, but in virtue of some consideration, of some relation established from outside: from the mind. It is in the synthesis of judgement, expressed by a proposition, that what is per accidens, which in itself is only a coincidence, comes to be taken as an existent. That is why I said above that ens per accidens is a kind of propositional being, since it is in propositions that ens per accidens reaches the status of being. In external reality it is only something that happens, without an ontological density of its own.

To understand this thesis properly, we have to appreciate the difference that there is between ens per accidens and predicamental or categorial accidents. This is a point at which St. Thomas's .

15 In VI Metaphysicorum, lect. 2, n. 1178.

16 In V Metaphysicorum, lect. 9, n. 887.

17 Metaphysics, VI, 2, 1026 b 13-15. 


\section{TOPICOS}

approach clearly goes beyond that of Aristotle. ${ }^{18}$ Predicamental accidents are to be found under another heading of the meanings of being: the heading under which the categorial schemata are considered. For this reason, we need to be careful not to confuse the division of being into the per se and the per accidens with the division of being into substance and accidents. An accident, paradoxical as it may sound, is not an ens per accidens, but an ens per se. The predicamental accident has an essence, in its own way, albeit an incomplete essence, as St. Thomas says in De Ente et Essentia. ${ }^{19}$ It possesses a certain consistency of its own, a certain real unity in the nature of things, no matter how much its reality is only that of being a modification of subsistent being, that is, of substance. As Aquinas says, being is divided into substance and accidents according to a non-relative consideration of being: that is, by paying attention to the kind of reality that each thing has in itself. Paleness, considered in itself, is a colour, a quality, an accident. Certainly, it does not exist in a separate way, independently of the substance in which it inheres: but it is something in its own right, it has a proper formality which delimits it, and differentiates it from other accidents and from the substance which sustains it. It can truly be said that the human being is pale, because this is what he or she happens to be. But he is not exactly what the pale is (id quod vere est album), since he or she is a person and not a colour. ${ }^{20}$

Ens per accidens, on the other hand, arises from a relative consideration of accident and substance. To continue with the same example, we have to consider not the pale in itself, but the fact that the human being is pale. The colour in itself is compared with the subject which happens to have it. This comparison is signified by the verb 'is', when we say that the human being is pale. The ens per accidens which is here set up is not the colour pale in itself, nor,

18 In V Metaphysicorum, lect. 9, n. 885.

19 De Ente et Essentia, ch. VI.

20 In IV Metaphysicorum, lect. 7, n. 628. 
obviously, the human being which has that colour. What is set up here is the construct pale-human-being. For this reason, the ens per accidens is, as Aquinas would say, hoc totum, this whole, signified by the proposition 'the human being is pale'. We can conclude, then, that the division of being into substance and accidents is one that pays . attention to what something is, according to its nature, whether it be substance or accident; while in the division of being into per se and per accidens attention is paid to the fact that something is predicated of something else, either per se or per accidens. ${ }^{21}$

We are here dealing, then, with a logical-semantic point of view, since the criterion we use to distinguish between what is a per se being and what is a per accidens being is drawn from the modes of predication: all from a point of view which we earlier labelled "formal". According with the theory of predication which St. Thomas formulates in question thirteen of the first part of the Summa, the predicate -of which the copula is a part- has the character of a form, while the subject has the character of a matter. ${ }^{22}$ The copula -the formalizing element in a predication- does not have the same value in the case of a per accidens predication as it has in the case of a per se predication. In the latter kind of predication, we say of the reality signified by the subject something that is intrinsic to its essence, or, at least, something inseparable from it (proprium). The copula 'is', in per se predications, has a real, existential scope. There is, can be, or must be something which is, in its own right, in . such and such a way. In per accidens predications, on the other hand, the copula 'is' has, in principle, a merely copulative, merely formal role, since it predicates of that which is signified by the subject something which does not belong to it in its own right: it only happens that it has it. ${ }^{23}$ The coincidence in which the per accidens consists (as the expression kata symbebekos suggests) is established or is at least

21 In V Metaphysicorum, lect. 9, n. 885.

22 Summa Theologiae, I, q. 13, a. 12.

23 Cf. KIRWAN, op. cit., pp. 143-146. 


\section{TOPICOS}

revealed in a predication: a predication which, from the modal point of view, is contingent, since it can be true or false. Ens per se, on the other hand, exists in its own right in the nature of things and is expressed by means of a necessary proposition. Since, in the distinction which we are making here, we are paying attention to the mode of predication and not to the mode of being, directly, the necessity in question is de dicto and not de re.

The difference between predicamental accidents and per accidens beings can be seen clearly when we consider the examples given in Book V of the Metaphysics. ${ }^{24}$ We say some thing per accidens, Aristotle points out, when we say, for example:

1) The one who is just is musical;

2) The human being is musical;

3) The one who is musical is a human being.

This three-fold classification of ens per accidens answers to a criterion which Aristotle expounds as follows: ${ }^{25}$ things said per accidens are said when:

1) Both occur in the same being, or

2) What is said per accidens occurs in some being, or

3) There exists that in which there occurs that of which the existent is predicated.

These three kinds of ens per accidens are related by Aquinas ${ }^{26}$ to three modes of accidental predication, which occur:

24 Metaphysics, V, 7, 1017 a 8-10.

25 Metaphysics, V, 7, 1017 a 19-22. 
1) When accident is predicated of accident;

2) When accident is predicated of subject;

3) When subject is predicated of accident.

The third case is the most interesting from our point of view, since it is the case that makes clearest the difference between ens per se and ens per accidens. The real relation that exists between the two determinations being a human being and being musical is that of inherence: the capacity of interpreting musical compositions inheres in a human subject. This relation, which we might call "natural", is inverted in sentences of the third kind, since what is predicated in them is the concept that represents the substance. A substance is never an ens per accidens, in its own right: but it can be taken as such, when it is predicated of an accidental determination which it itself has. If we say 'the one who is musical is a human being', what we are saying is that it happens (accidit) that the one who makes music is a human being. (Could it be otherwise? Perhaps it could be a singing bird or an electronic organ). And this is something that really happens, but which only is, properly speaking, in the proposition which sets up this peculiar relation.

For there to be beings per accidens there have to be beings per se. ${ }^{27}$ Without things there are not happenings; and happenings are not strictly speaking things. They are not, either, strictly aliquid, or one and the same, or true or good: the transcendental properties can be predicated of any per se existent, but cannot be said in any stróng sense of per accidens beings.

26 In V Metaphysicorum, lect. 9, n. 886.

27 In XI Metaphysicorum, lect. 8, n. 2228. 


\section{TOPICOS}

It is not surprising, then, that the scholastic tradition has preferred to deal with ens per accidens as logical accident. This, unlike the ontological accident, is to be found among the predicables, not the predicaments. This approach had already been anticipated by Aristotle, when, in the Topics, he defines the accident as something that belongs to a thing, but which is not a definition, nor a proprium, nor a genus; or, better still, as that which can occur or not occur in a thing. ${ }^{28}$

The expression 'accident' is expounded in Aristotle's philosophical lexicon and is given, first, the sense of the predicable accident: "What is called accident is what certainly occurs in something and can be truly attributed to it, but not necessarily or for the most part". ${ }^{29}$ The two examples which Aristotle uses to illustrate his definition are classed by St. Thomas as referring to accidentality in becoming (fieri) and accidentality in being (esse), respectively. ${ }^{30}$ The first of the two examples has passed into the history of art, through being the object of numerous illustrations in medieval books. Its attraction lies, perhaps, in the fact that it is a rare occurrence: fortune is for once favourable to the chief character in the story, and -a still more rare occurrence- befalls not when he is playing dice, but when he is working in his garden one boring weekend. A man, digging a hole to plant a tree, finds a treasure. Finding a treasure is indeed an accident for the one digging the hole, since finding a treasure does not necessarily follow from digging a hole, or after digging a hole. Nor, alas, does it happen for the most part that the one who is planting a tree finds a treasure. The second example is as follows: a musician can be pale. This is called an accident, since this happens neither necessarily nor for the most part. ${ }^{31}$ The propositions which state these facts are not necessary, since they express that something occurs in

28 Topics, I, 5, 102 ? 3 4-7.

29 Metaphysics, V, 30, 1025 a 14-15.

30 In V Metaphysicorum, lect. 22, n. 1139.

31 Metaphysics, V, 30, 1025 a 15-21. 


\section{COINCIDENCE AND NECESSITY IN AQUINAS}

something else, but not exactly in virtue of being that something else, ${ }^{32}$ or in virtue of being in the condition in which it really is, but by a pure coincidence, which has no relation to the end of the action or the present state of the world. This is what happens, says Aquinas, when paleness is said of the musician, since paleness is not something that belongs to a musician in so far as he or she is a musician. Likewise, it is purely contingent that there should be heavy rain in summer, because this is not something that happens in summer in so far as it is summer. It is also per accidens if a heavy body is up high, since it will not be in such a high place in virtue of what that place is, but for some extraneous cause. ${ }^{33}$ So, in all these cases, and in an infinity of others, the accident has been produced, or exists, but has not been produced in so far as it is what it is, but in so far as it is something else; it does not exist in so far as it is what it is, but in so far as it is something else. ${ }^{34}$

What we are faced with here is clearly the mode of being which is proper to ens per accidens, which is, in fact, a wholly improper mode of being. The per accidens is something outside the scope of the finality which, for each thing, establishes its proper nature, and, for each free action, establishes the purpose which guides it. The per accidens does not exist according to an act of having or an acting which is proper to it, which belongs to it in its own right, but rather exists according to an act of having or an acting which, in reality, belongs to something else. It can, as mere hap would have it, be said of that which is per accidens, but not in any necessary way. The truth of the proposition in which the existence of the per accidens is affirmed has no more constancy or stability than that mere hap has. It is not always true, it is not even for the most part true: it is only sometimes true.

32 Metaphysics, V, 30, 1025 a 23.

33 In V Metaphysicorum, lect. 22, n. 1140.

34 Metaphysics, V, 30, 1025 a 28-29. 


\section{TOPICOS}

In spite of the secondary or derived character of this accidental mode of being -which is the weakest mode of all- recognizing it is of the greatest philosophical importance, since it reveals to us that the world we experience is not a closed whole. Our world is not a homogeneous seamless web, a univocal reality: it is plural, differentiated world, a world which is never completely determinate, a world in which order never succeeds in completely imposing on disorder. In the physical world, order is a limit of disorder, as contemporary physics shows us; and in the moral world, human justice can only aspire to being a limit of injustice.

The aim of imposing a total justice leads to a nearly total injustice. The political philosophy of Aquinas takes account of the fact that human freedom gives rise to accidentalities that cannot be brought under the laws. For this reason, it attributes an architectural function to political activity, a function which never reaches to the bottom of social . reality, which does not rule out opposing visions or disagreements. Utopian thought, on the other hand, aims at exhausting a complete political rationality, as the perfect realization of a seamless ideological configuration. Modern political thought therefore finds it very hard to make compatible the essential equality of all human persons with their accidental inequalities. For this reason, it oscillates continually between totalitarianism and relativism, and quite often offers us a mixture or suspension of the one error in a solution of the other.

Our world is not a perfectly put-together set of pure essences, which reason can pierce through and through, to its depths. I do not mean, by this, to deny that there really are essences: the necessary mode in which each thing exists, its own way of having itself, which constitutes it as what it is. But there is also that which is not according to essence, that which is according to something other than essence. And our way of talking -which follows on from the way of being in reality- recognizes this strange mode of being, a mode so strange that it orushes the limits of non-being. Hence, besides 
necessary propositions -i.e., besides the modi dicendi per se- we have to make use of true contingent propositions, in which we set up as beings what are really no more than chance happenings, coincidences of realities or combinations that have no reason for occurring together. We use expressions involving being in different senses in order to match reality, which is not a monolithic block, nor absolutely necessary. The point at issue is not that, as St. Thomas often reminds us, the essential forms of most things are unknown to us. The point is that worldly realities are not completely determined by the essential forms of things. They are not just what they are by essence; they are also, in a very different way, what they are by accident. Indetermination really exists.

Coincidental being really exists, in the sense we have been identifying. If this were not so, all things would be of necessity. But, as Aquinas points out, not everything that happens has a per se cause, a cause from whose existence the existence of the effect would necessarily follow. If it did, then everything that happens would happen necessarily. ${ }^{35}$ If everything were necessary, there would be no future contingents, since any occurrence would be univocally determined by another, and that other by yet another, and so on. In this way, at the present moment all the elements which entirely determine the future would already be present; and, at the same time, the explanation of what is happening now could be sought back in the past. But that is not the way things are: when we go back into the past we reach occurrences which have no proper cause, but which occur by accident ${ }^{36}$ At these points the process of causal explanation is stopped, and the causal series itself finds its earlier limit, since we have run up against what Aquinas calls the causa casualis. Let me

35 In VI Metaphysicorum, lect. 3, n. 1191. Cf. Chevalier, J.: La notion du nécessaire chez Aristote et ses predécesseurs, A. Rey, Lyon, 1914, pp. 19-20.

36 Metaphysics, VI, 3, 1027 a 30 - 1027 b 14. Cf. SORABJ, op. cit., pp. 325. 


\section{TOPICOS}

insist that not everything that happens has a per se cause; per accidens beings have only a per accidens cause. ${ }^{37}$ But this accidental cause is not, strictly speaking, the cause of anything, since it is called cause only in an improper sense. And, since nothing accidental is prior to what is in its own right, accidental causes cannot, in the end, be prior to per se causes. So though luck (fortuna) and chance (casus) can be put forward as if they were causes, in a prior way understanding (intellectus) and nature (natura) must be causes. ${ }^{38}$ If, in spite of everything, we have to have recourse to per accidens being, it is because the necessity we recognize in our world is not usually complete. This is shown by the fact that most things are not everlasting. Most things that happen do not always happen, but only for the most part (ut in pluribus). Now, if there is something which is not always, but only for the most part, there must also be a kind of. remainder or supplement of what happens for the least part (ut in paucioribus), i.e., ens per accidens. This is because if what happens for the least part never happened, what happens for the most part would always happen: it would thus not be for the most part, but forever, and necessary. And this is not true. Hence Aquinas can conclude that it is necessary that what exists per accidens should exist (necesse est esse quod est per accidens). ${ }^{39}$

This last phrase reveals a singular paradox: it is necessary that the per accidens beings should exist. It is necessary that the contingent should exist. It is necessary that the non-necessary should exist. Surprising as it may sound, these sentences are not only true, but disclose one of the most interesting connections of thought in St. Thomas's ontology. Let us begin by drawing attention to one of its semantic properties. For the paradox to avoid flat and blatant

37 In VI Metaphysicorum, lect. 3, n. 1201.

38 In XI Metaphysicorum, lect. 8, n. 2288. Cf. AlviRA, R.: "Casus et fortuna en Sto. Tomás de Aquino", Anuario Filosófico, X/1, 1977, pp. 2770.

39 In VI Metaphysicorum, lect. 2, n. 1186. 


\section{CONCIDENCE AND NECESSITY IN AQUINAS}

contradiction, we have to distinguish two senses of 'necessary' in the proposition 'It is necessary that the non-necessary exists'. In its first use, the word 'necessary' works as a second-level predicate, de dicto; at its second occurrence, it works as a first-level predicate, de re. The first use is said of an expression, in sensu composito; the second use is said of a real subject, in sensu diviso. It is necessary (because it is always true) to say that there are things which are really non necessary, i.e., per accidens beings. This is quite compatible with what we said of the de dicto non-necessity of the propositions in which an ens per accidens is formally constituted, so to speak. There is nothing to stop us recognizing latter that to this contingent mode of expression there corresponds a contingent mode of being -an improper mode- which is one of the ontological characteristics of ens per accidens. And there is nothing to stop us going on, as we do now, to assert that it is necessary that there should be things with this contingent mode of being.

From an ontological point of view, we have to have recourse to matter if we are to understand the paradox which has been raised by the connection between the necessary and the non-necessary in relation to coincidental being. In this world it is a necessary fact, not a contingent one, that there are material beings. This is because it is necessary that matter (in the sense of prime matter) exists. The presence of matter is necessary, since, as the permanent subject of generations and corruptions, it is neither generated nor corrupted; and this, even though matter in itself possesses no necessary determinations. It is matter, then, that is responsible for, or is even, in an improper sense, the cause of the fact that there are accidentalities, contingencies, coincidences or chance meetings. We could say that matter is a necessary, but non sufficient, condition for the nonnecessary. In fact, as Aristotle says, "matter (hyle), which admits of existing in another mode from that which is for the most part, will be 


\section{TOPICOS}

the cause of the accident" ${ }^{40}$ Now, to say that matter is the cause of the accident means that there is no determinate cause of coincidental being, since matter is the principle of indetermination. The fortuitous, contingent "cause" of coincidental being will thus be chance, and this is indeterminate. ${ }^{41}$ It is necessary, then, that chance should exist: chance, which is, as it were, the cause of that which has no proper cause.

From this point of view, we can see clearly that ens per accidens is outside the scope of teleological processes; it lies outside final causality. In the case of physical beings, it is something that happens unrequired by the nature of the things that come together in the occurrence; in the case of free choices, it is what is outside the agent's intention (praeter intentionem) which is accidental and fortuitous. For example, it was by accident that the traveller arrived to Aegina when his intention in boarding ship was not that of reaching that city, but was taken there because the ship was driven from its course by a storm, or because he was captured by pirates. In such a case, reaching Aegina is per accidens and could be brought about by various causes. It is not in so far as he was sailing to Aegina that the traveller gets there; rather, in so far as these things happened to him. He cannot say that he sailed to Aegina, since the aim of his journey was somewhere else: rather, he should say he was brought to Aegina by a cause which had nothing to do with the aim of his sailing. The bad weather, the pirates, the error of the helmsman, or whatever else, is the cause of the traveller's reaching a port he was not sailing to. ${ }^{42}$

40 Metaphysics, VI, 2, 1027 a 13-15.

41 In V Metaphysicorum, lect. 22, n. 1141. Cf. Metaphysics, V, 30, 1025 a 24-25. Cf. WEIss, H.: Kausalität und Zufall in der Philosophie des Aristoteles, Falken, Basel, 1942, pp. 44-48. Cf. FrEDE, D.: "Necessity, Chance, and 'What Happens for the Most Part' in Aristotle's Poetics", in RorTY, A. O. (ed.): Essays in Aristotle's Poetics, Princeton University Press, Princeton, 1992.

42 In V Metaphysicorum, lect. 23, n. 1141. 


\section{COINCIDENCE AND NECESSITY IN AQUNAS}

With regard to this point, Aquinas's position is not fundamentally different from Aristotle's. But his creationist metaphysics necessarily introduced a new dimension into the scene. St. Thomas admits, with Aristotle, that accidental occurrences are those which are outside the intentions of finite agents, or outside the natural action of particular causes. This is what happens, for example, when two proximate causes coincide in the production of an event, and neither is ordered to the other; or when the weakness of an agent means that it does not reach the end pursued; or when defect of matter means that it does not receive the form which the agent was trying to impress on it. ${ }^{43}$ But if these contingencies are referred back to the divine cause, nothing that is in them is left outside the order prescribed by God. Not even matter, with its intrinsic indetermination and its possible defects, can obstruct the divine command which extends to all beings in so far as they are beings. This is because, though change requires matter, being as such does not. The cause which confers being cain be obstructed neither by matter nor by any circumstances which supervenes on being. ${ }^{44}$ In so far as they are to be referred to the first cause, all things have an order: and, in this sense, their mode of existence is not per accidens. This does not exclude their being per accidens in relation to other particular and proximate causes. That is why, Aquinas reminds us, the Catholic faith teaches that nothing happens by chance or at random in this world, and everything is subject to divine providence. Aristotle, at least when dealing with ens per accidens, limits himself to considering particular causes. ${ }^{45}$

St. Thomas thus gives a solution to the problem of the compatibility between the existence of coincidental being and the universality of divine providence. This solution has, as a presupposition from a semantic point of view, the distinction we have mentioned between de $r e$ an de dicto necessities. This presupposition is made explicit in

43 Cf. In VI Metaphysicorum, lect. 3, n. 1210.

44 In VI Metaphysicorum, lect. 3, n. 1215.

45 In VI Metaphysicorum, lect. 3, n. 1216. 


\section{TOPICOS 。}

question 14, article 3, of the first part of the Summa Theologiae, and also in the Quaestio Disputata de Veritate, question 2, article 12,46 where Aquinas esiablishes a distinction between ontological and epistemic necessities, which is echoed in an interesting way in. contemporary authors such as Michael Dummett and Saul Kripke. ${ }^{47}$ From a metaphysical point of view, the doctrine which is at the basis of St. Thomas's solution, as we have just seen, is the transcendental character of the creative and provident cause, which is to be situated in an order distinct from the categorial level at which secondary causes operate. Divine providence cannot fail: that God should foresee that $p$ and that $p$ should not occur are not compossible. Once divine providence is granted, the effect follows of necessity. ${ }^{48}$ But the necessity here is an external, de dicto necessity. The conditional sentence 'If God foresees that $p$, then $p$ ' is true, and every true conditional is necessary with de dicto necessity (necessitas consequentiae). ${ }^{49}$ But transcendental causality, precisely in so far as it is transcendental, does not interfere in the causality of proximate causes, nor substitutes them; and it is these proximate causes that determine whether an effect is contingert or necessary. We are now dealing with the necessity (necessitas consequentis) and contingency which are internal to the thing itself, which affect its characteristic properties. Thus the fact that the conditional sentence 'If God foresees that $p$, then $p$ ' is necessarily true does not remove the alternativity of the necessity or contingency of the effect considered in itself. This does not mean that the omnipotent character of this prediction is undermined: rather it means recognizing it for what it is. According to Aquinas, not only being as such but also the modes of being are subject to divine providence: and among these modes are necessity

46 Summa Theologiae, q. 14, a. 13, ad 3; De Veritate, q. 2, a. 13, ad 4. 47 Cf. Dummett, M.: Frege: Philosophy of Language, Duckworth, London, p. 117; KRIPKE, S.: Naming and Necessity, Basil Blackwell, Oxford, 1980, pp. 34-36.

48 In VI Metaphysicorum, lect. 3, n. 1218.

49 Cf. In XI Metaphysicorum, lect. 5, n. 2218. 
and contingency. ${ }^{50}$ Nothing that happens, however fortuitous it may be, is outside God's providence: thus God's providence does not destroy the accidentality of the per accidens.

As I said before, admitting ens per accidens among the senses of being has a decisive influence on Aquinas's conception of reality, and on his metaphysical focus. As we have seen, coincidental being is not included within the object of first science: but it is precisely this exclusion which makes the science of metaphysics possible. The distinction between beings in their own right and coincidental beings allows us to notice that in the world of experience, in the complex of finite things, not everything is necessary and not everything is contingent. (Strictly speaking, indeed, there is nothing in this world of ours that is so necessary that it does not have some traces of accidentality, and nothing is so contingent that it doss not imply some kind of necessity). "In addition", as it were, to what exists in its own right, and which possesses the stability which its nature confers on it, we have what is in a coincidental way, which is affected by the ephemerality which derives from the fact that it exists in virtue of something outside its own essence. The limited and finite character of what exists in a proper sense is complemented, so to speak, by the factor of otherness, of negativity, which is brought in by what exists in an improper manner. Aquinas's metaphysics is continually aware of the presence of this kind of non-being. Even though it cannot be made the object of scientific consideration, metaphysics is aware of it in its investigation of the structure of finite being. Thus we cannot clarify what is metaphysical finiteness without recognizing the presence of accidentality, which necessarily accompanies all limited things. Recognizing this fact is indispensable, if St. Thomas's metaphysics is to steer clear of the rationalism which has infected certain varieties of neo-scholasticism, and find its own way: a way which matches human nature and the character of the world. In this

50 In VI Metaphysicorum, lect. 3, n. 1220. 


\section{TOPICOS}

way, the metaphysics of Thomas Aquinas can be established, formally, as an ontology, a study of realities other than pure existence, pluriform entities, which are limited and at the same time open to further determination. Only the recognition of the relative lack of consistency of finite beings will allow us to climb above them, not by dialectic but by analogy, to the Esse subsistens per se. The metaphysics of Aquinas is an ontology, from a formal point of view, but also a natural theology, from a final point of view. This being so, accidental being appears in all realms of philosophical investigation. Professor Amalia Quevedo, in her full and exhaustive book on ens per accidens, has examined the whole of this aspect of reality, which we could call "the back of the tapestry". 51 I shall finish by drawing attention to one of the problems in which the importance of this distinction appears most clearly, and the distinction is shown to be far from triviality or technicality: the problem of human freedom.

Even though the dispute between determinism and indeterminism is a typically modern one, it is possible to say that in the world of Aquinas there is both determination and indetermination. ${ }^{52}$ Hence St. Thomas's position could be called either "limited determinism" or "limited indeterminism". 53 As Professor Peter Geach has pointed out, "contingency in the physical world is a necessary condition of human freedom. A man is not free unless some observable movements of his body are up to his own decision; so he is not free if his movements are predictable from some set of factors in the world that can be specified in a way that takes no account of his decisions. A man is not free in speaking if some set of causal factors that takes no account of his mind and will in speaking suffice to determine what sound-waves

51 QUEVEDO, A.: “Ens per accidens". Contingencia y determinación en Aristóteles, EUNSA, Pamplona, 1989.

$52 \mathrm{GEACH}$, P.: Providence and Evil, Cambridge University Press, Cambridge, 1977, p. 120.

53 Cf. INCIARTE, F.: "Freiheit und Determinismus", Atti del IV convegno di Studi Settimane Mediterranee, Manfredi, Palermo, 1979. 
issue from his lips; he is not free about smoking, given that cigarettes are within reach, if causal factors quite apart from his own thoughts and intentions guarantee that his hands will pick up and light cigarettes and his lungs inhale and exhale the smoke. It is mere bluff, as I said, that such predictions as these are already feasible; it is a mere impious hope to say that they will become feasible when we. know a bit more science".

"At this point", Geach continues, "it is often objected that a freedom which consists in our actions being chancy and unpredictable is not something we ought to haker after. I concede the point but I deny its relevance; for what I am arguing is not that macroscopic physical indeterminism is a sufficient condition of human freedom, but that it is a necessary condition; the examples of the speaker and the smoker point up the incoherence of the Leibniz-Pope position about Almighty God, which

\section{binding Nature fast in fate}

Let free the human will

If men are to act freely there must be both some determinism and some indeterminism in the world". 54

The Leibniz-Pope position is clearly incoherent; but so are the positions of some recent Thomists who have tried to make compatible an admission of human freedom and a complete determinism in the world, understood in a rationalist way: an understanding of the world in which there would be no room for the entia per accidens, a world which, therefore, would bear little resemblance to the world as Aquinas understood it. By trying to give a Cartesian dualist reply to the problem of freedom, they fall into what is called the "homunculus fallacy" or "manikin fallacy", which leads us inevitably to answer by begging the question.

54 GEACH, op. cit., pp. 119-120. 


\section{TOPICOS}

Human affairs, says Aristotle, have their origin in deliberation and action. ${ }^{55}$ If, on the contrary, everything were to happen by necessity, we would not need to deliberate but merely to execute. ${ }^{56}$ Not that human affairs are uncaused: their cause is in free human action. But free will introduces into nature a causal series whose connection with antecedent situations, and with the material or social context, is not a per se but a per accidens connection: i.e., an indeterminate one. Human action in the material world is a source of accidentality, but human action is not a cause of the per accidens in the way that matter is. It does not introduce a factor of indetermination, but rather an intelligible, voluntary determination, which is irreducible to any physical determination. The articulation of this determination and this indetermination here is of the greatest importance for a theory of. freedom: but this is not the moment to develop it.

A last observation: as Aquinas and Aristotle often point out, the past, in so far as it is past, is necessary. "For this alone is lacking even to God, to make undone the things that have been done", as the ancient poets said. But the necessity of what has happened, in so far as it has happened, is not passed on to the things that have happened, in so far as they are these or those things: it is an epistemic, not an ontological necessity. However past a contingent event, a coincidence or a free action, may be, it does not eo ipso become a necessary event. What is necessary is for us to say that it has happened. This is the necessity which makes history a scientific study: and it also makes a scientific study of theology, which studies the free saving initiatives of God towards the human race, as a history of salvation.

55 De Interpretatione, 9, 16 a 6-9. Cf. Weidemann, H.: Aristoteles: Peri ' Hermeneias, Wissenschaftliche Buchgesellschaft, Darmstadt, 1994.

56 De Interpretatione, 9,18 b 1-3. 
Copyright of Tópicos. Revista de Filosofía is the property of Universidad Panamericana and its content may not be copied or emailed to multiple sites or posted to a listserv without the copyright holder's express written permission. However, users may print, download, or email articles for individual use. 